\title{
A discussion on child-friendly cities through a critique on the experience of the body
}

\author{
Nevset Gul Canakcioglu*
}

\begin{abstract}
Social changes resulting a significant shift in philosophical thinking in the renaissance brought the idea of individuality to the forefront, radically changing the social requirements and desires of individuals, the ideas of freedom of all individuals collectively, their relations with society and their environments, and also their participation in urban life. As a result of the industrialization activities, wars and migrations experienced in the twentieth century, this direct participation of the individual in the urban space was negatively affected. Especially due to globalization, the changing physical appearance and quality of life of metropolitan cities have created disconnections in human interactions with the city and their bodily experience with the environment. Monetary system which has dominated urban life, has taken business life to the forefront separating the residential fabric from the zones where business life has developed, and accordingly lively streets have been surrendered to motor vehicles over time.

One of the social groups mostly affected by these changes, is the young generationchildren. The sacrificed areas in the cities, where the scale has changed radically, were usually the recreational environments, and children's play areas. Within this context, it is also mentioned in the literature that adults (politicians, planners and municipalities) easily ignore the fact that cities are also for children; the developmental characteristics of young people, their needs for age, play and experience necessary for their healthy growths are ignored.

Therefore, it should be admitted that cities should have a lot to offer children. It is necessary to organize the streets, to plan the transit routes of motor vehicles, redefine new speed limits, and re-evaluate the streets to make them pedestrian-friendly again taking into account the possibility of danger to children. So, as a part of the theoretical background discussed in the context of environment and behavior theories, the debate covers how the urbanites, children in particular - very urbanite is considered as a body in this paper-are affected by the rapid change of urban space.

Also, through the introduction of global models such as woonerf and home zone on how the city can regulate physical and social components that can contribute both to the socialization of adults and to children's development and freedom in relation to their own age and needs, a fruitful insight is endeavored to be provided to the potential for these kinds of practices to be implemented in metropolitan cities especially in the residential fabric.
\end{abstract}

Keywords: bodily experience, children's play, environmental psychology, home zone, woonerf.

\section{Introduction}

In Turkey, especially since the 1980s, increasing globalization movements have led to significant changes, especially in metropolitan cities where large companies have headquarters and economic 
activity is concentrated. But, with the new physical condition that changed the old neighborhood scale to a much different look in the city damaged the spatial interaction, dialogue and bodily experience of the individual between the pedestrian and physical environment that used to exist on the neighborhood scale, brought about by mixed use. Unfortunately, these changes in the city have hurt children the most who have been deprived of the opportunity to play on the streets in their neighborhoods.

Page $\mid 70$

Bettleheim (1987) suggests that adults (politicians, planners, and municipalities) often ignore the developmental characteristics of the children and young people, their needs for age, play, and active experience. As a matter of fact, for some adults, childhood is only a transitional stage, and therefore there may be many overlooked points in addressing urban planning on a holistic and participatory basis. For this reason, it remains unclear exactly which components of the environment are important to children. Failure in allowing children the opportunity to speak publicly about their wishes and needs (Spencer and Woolley, 2000), and perhaps their lack of political power because they do not vote, may also have an effect on this result (Churchman, 2003).

Arza Churchman (2003) questions whether children have a place in the city and she uses the concept of place here in both a physical and symbolic sense. In the physical sense, she questions whether the city offers safe and pleasant places for the bodily experiences of children, and in the symbolic sense, she questions whether the city gives children a message that they are equal members of the society, both within the framework of the city's design and planning and in the context of the attitudes and behaviors of adults living in the city.

This paper examines how the changing urban form has changed the individual's experience and perception of the body because of the disconnections of the individual's interaction with the city as a result of changes brought about by social and physical changes, especially at what level it affects the youngest people of society. In the study, the concept of the youngest generation of the society is defined with the first article of the Convention on the Rights of the Child (UNCRC, 1989, Article 1): "a child means every human being below the age of eighteen years unless under the law applicable to the child, majority is attained earlier." Furthermore, the argumentation in this paper is based on the 31st article on the prioritization of the child's right to engage in play and recreational activities play as stated in the thirtieth article of the same declaration (UNCRC, 1989, Article 31): "States Parties recognize the right of the child to rest and leisure, to engage in play and recreational activities appropriate to the age of the child and to participate freely in cultural life and the arts."

For the examination, first of all, the relationship between the body and the environment is endeavored to be evaluated through a philosophical point of view. In other words, this study aims to understand, how the bodily experiences of the individuals, especially children in particular, are increasingly ignored in globalized metropolitan cities through a philosophical debate concerning the perception of the body. Later on, recognizing the fact that these changes in progress will in fact be endlessly and inevitably continuing in cities, some opinions and models developed in the late 1900s in Europe -woonerf and home zone- are presented since it is thought that those models which have also been applied in many countries outside Europe and positive results have been achieved in evidence-based studies, might give a fruitful insight for the decision makers in metropolitan cities of Turkey.

\section{Theoretical Background}

Descartes, as the father of modern philosophy in the seventeenth century, suggested that the only way to discover one's ontology is because the one knows that s/he thinks; as he expressed this idea with cogito ergo sum as his famous expression (von Leyden, 1962). But, in the twentieth 
century, the phenomenological thinking in philosophy had ended the Cartesian method of analysis which was evaluating the world as consisting sets of objects and the relations of objects with other objects. The phenomenological ontology on the other hand, has spread widely and opened a new gate in philosophy, primarily considered with the study of the consciousness.

For Husserl, who can be considered as the father of the phenomenological thinking, the first battle was to rescue the judgment from the effects of metaphysics. According to Husserl, the mission of philosophy was to reveal judgment with its new freedom and characteristics; so metaphysical way of thinking must have been completely separated from judgmental way of thinking (Akarsu, 1994). According to French historian Bernard Andrieu, twentieth century can be characterized by an 'epistemological dispersion of the human body'. This shift of the body and the importance of the person as a being was primarily the result of theories emerging from psychoanalysis, phenomenology and cognitive science. The influence of these fields, moreover affected the artistic practices in the contemporary media art and in architecture as well. It is not an exaggeration to say that over the last decades the study of the body has dominated many critical disciplines in the humanities, to the extent that a new discipline has arisen: that of a body criticism (Wegenstein, 2006).

The 'body' debate becoming a current issue, owes its starting point to Merleau-Ponty. So, in this paper, the shift of thinking from pure absolute object world to a world of experiential and existential thinking and locating the man just in the center of everything is tried to be explained with the proceeding history of philosophy in the scope of environment and behavior theories. The theoretical part of the paper will be giving place to significant thinkers to cover the significant change in philosophy of experience and the body as a subject interacting with the entire world such as Merleau-Ponty, Husserl, and Heidegger.

The enactive approach to bodily experience and perception draws on a number of distinct traditions in philosophy, psychology and cognitive science. The character of vision plays an important role in Merleau-Ponty's philosophical writing and in other philosophical works of phenomenologists. According to Merleau-Ponty (2010), in psychology, like in geometry, in the 20th century, human body with its all characteristics and with its 'thrown into the world' situation -as Heidegger says- is replaced by the consciousness without a body. Human is in fact, not a body and a soul separated from each other but rather a body with a soul. We, as humans, can reach to everything by our body so that every existence becomes a mix of soul and body.

In the context of human experience, there are such qualities that are impossible since it becomes meaningless to isolate them from reactions that our bodies awaken to certain impacts (MerleauPonty, 2010). In this context, Merleau-Ponty (2010) exemplifies human's experience with honey as a metaphor; honey is a slow liquid and has a certain consistence -it cannot be held permanently in the hand, pours and continuously flows down from the hand. The experience of the human with the honey reverses the roles with the holder because it makes the hands so sticky. While the hand thinks that it is dominant to its object, it is immediately caught by its materialistic characteristic. Such an interaction between the human body and honey can only be understood through a dialog. The relationship between us and objects is not remote, every object appeals to us and our life, takes the role of humans; reverse is also valid, these objects live as symbols of our behaviors. Man invests to objects; objects invest to men (Merleau-Ponty, 2010).

So, according to Merleau-Ponty (2010, p.70) it should be accepted that, in science, art and even in our daily acts, neither is there dogmatism nor a sense of self-confidence in modern thinking. Thus, this intertwined, complex relationship of the kind depicted by Merleau-Ponty between the 
body -individual- and the materialistic -built- environment can only be understood through an existential and experiential intellectual way of understanding.

\subsection{Bodily Experience within the Context of Environment and Behavior Theories}

Environment and behavior theories which analyze such an intertwined and complex relationship between the body and physical environment through a multi-disciplinary discussion such as psychology, sociology, and anthropology covers the research issues investigating design principles shaping spatial attributes. Werner and Altman (2000), similar to other researchers working on environmental psychology, define the relationship of humans with the environment as how humans affect the nature and built environment and also how they are affected from them. So, researches on environment behavior theories consists of research areas from wayfinding and privacy issues to how people use work spaces, entertainment and social places, functionality of spaces, neighborhood relations and etc.

So, it can be argued that people generally have a sense and perception of place depending on the process of their experiences and interactions in various environments which lead them to behave in certain ways, whether they are consciously aware of it or not. Hurley names the view of the relation between perception and action as the input-output picture (Noe, 2004). Perception is the input from world to mind, while action is the output from mind to world, and thought is the mediating process. On the other hand, Noe (2004) describes perception as something that we do and the world makes itself available to the perceiver through physical movement and interaction. On the other hand, being a perceiver is to understand, implicitly, the effects of movement on sensory stimulation.

However, the physical, social and economic changes experienced after the 1980s, especially in metropolitan cities, gradually increased the distance between the perceiver and the perceived. According to Keyder (2009), rapid globalization movements found reflections in Istanbul in terms of not only economically and sociologically but also physically, as was the case all around the world. Istanbul has been globalized by the intensification of global money, investment, and information circulation generally, and changed in terms of urban land, too.

\subsection{Body and the City Interaction within the Context of Globalization}

The globalization movements in most of the metropolitan cities made the construction field as the most profitable sector and turned the real estate properties to be used as an investment tool. Major construction companies have started to build office buildings, shopping malls, five-star hotels and also very large housing units mainly in Istanbul. Differentiation of the consumption habits, income levels and free labor market and change in workers' profiles encouraged people to travel to other global cities and achieve to purchase new houses through mortgage loans. So, the city, while it was being occupied by informal housing clusters of low-middle class migrating to the city since the 1950s on the one hand (Tas and Lightfoot, 2005; Dicle, 1983), it was also being covered by new gated communities (Kurtulus, 2011) where the residents expected a privileged urban experience that can be symbolized as a desire for "elite urbanism" (Geniş, 2007, p.773). Besides, high-rise headquarter buildings of international companies on fringe-belts (Kubat, 2019), and sky towers as residences were keeping the "urban elites" (Baycan Levent and Gülümser, 2004, p.6). The reflection of such a separation of social groups in the city had started to be symbolized more harshly in the physical space tough and vice versa. 
Beside the globalization issue, internet and similar information technologies made the body to reach a lot of data easily, collect information from many sources and disciplines and made it easier to synthesize them with various ideas but on the other side alienating the body to experience, context and history (Moussavi, 2010). Within this context, in the scope of this paper, main reason of the heavy disengagement of the body and the city which is mainly observed in metropolitan cities are based on the reason of globalization which made most of the metropolitan cities as parts of capital market like some other worldwide capital cities. Accordingly, the physical appearance of today's environment in terms of architecture together with urban design resulted because of the continuous changes in urban lands is thought to be the reason that prevents the interaction of the body and the built environment causing the obstacle of the experience of the body. According to the researcher, such a phenomenon can be easily read through the flow of streets which are the capillaries of the city and also the sidewalks since sidewalks can be considered as in-between spaces where the body as a pedestrian interacts with the built environment.

\subsection{In-between Space of the Body in the City: The Sidewalk}

According to Jacobs (2011), objects in cities - whether they are buildings, streets, parks, districts, landmarks, or others- can have radically different effects, depending upon the circumstances and context in which they exist. On the other hand, streets are for many purposes as well as carrying vehicles and even pedestrians. "A city sidewalk by itself is nothing. It is an abstraction. It means something only in conjunction with the buildings and other uses that border it, or border other sidewalks very near it. The same might be said of streets, in the sense that they serve other purposes besides carrying wheeled traffic in their middles. Streets and their sidewalks, the main public places of a city, are its most vital organs. Think of a city and what comes to mind? Its streets. If a city's streets look interesting, the city looks interesting; if they look dull, the city looks dull." (Jacobs, 2011, p.106).

Jacobs (1992) argue the purposes of sidewalks under three main titles such as the concepts of (1) safety, (2) contact, and (3) assimilating children. Considering the safety issue, there should be a specific border between the public and private spaces. They should not penetrate into each other as it is done typically in suburban housing. The concept of 'eyes upon the street' is also a very important issue according to Jacobs (1992), since the ground floors opening to sidewalks behave like the natural landowners of the street. On the other hand, the sidewalks should necessarily have users at all times of the day continuously to be a safe place. Regarding the concept of contact, she supports the idea that the sidewalks are places that bring people together who do not know each other intimately; a good street in the neighborhood should achieve a good balance between its people's determinations to have vital privacy and their simultaneous wishes for differing degrees of contact, enjoyment or help from the people around. Considering the concept of assimilating children, Jacobs (1992) had discovered that especially child gang battles occur in such places designed only for children like playgrounds and parks. Because the streets in the cities sheared the children play on the streets, where children are not in the sights of adults. So, the most significant change happened is that the children moved from the eye control of a high numerical ratio of adults. Even some of the children Jacobs interviewed told that if they had wanted to do anything antisocial, they had always gone to some parks because none of the grown-ups would have seen them there.

Consequently, the importance of sidewalk is so significant to create a lively and self-interactive city since interactivity means the close and direct relationship between the living and non-living one, the human, the building and, also the environment. In other words, interactivity brings safety on the street, affects preferences where people want to live and work, increases sense of belonging which all affects the sense of place and encourages different social groups come together from 
different socio-economical levels and age groups which all together affect the social synergy in the society.

On the other hand, the scale of the built environment interacting with the pedestrian especially at the nearest level is the other significant issue since the use and facility of the building is the source of communication like the eye and mouth talking with the body on the street. For instance, whether the use of a high rise building is only an office building, another function added to that building like an art gallery, or an outdoor space, or a passage way beneath the building consisting of retail areas open to everyone in the city can wipe out the enormous affect that squeezes the human and can change the perception of the body.

According to Bilgin (2006), one of the development strategies of Turkey in 1980s was emptying the city center while opening it to new facilities without doubt. It is accepted to make such a gradation to separate Central Business Districts (CBDs) such as management, supervision, finance, service, national and international trade facilities from other kinds of business types so that the distance between home and workplace is shortened in maximum (Akgün, 2010).

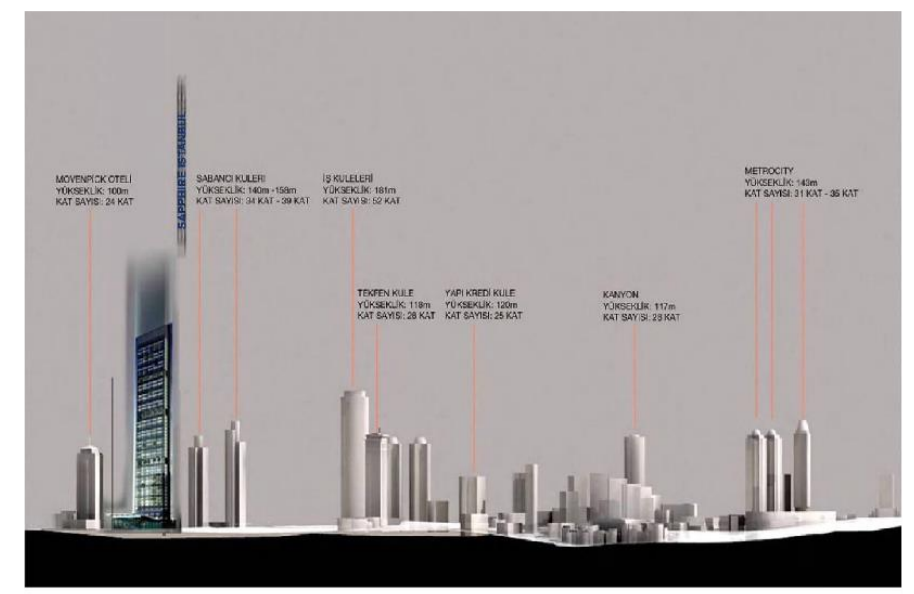

Figure 1 The scale comparison of Sapphire Building in the city of Istanbul (Akgün, 2010, from Tabanlığlu Archive)

As can be noticed from Figure 1, this strategy, which was implemented in metropolitan cities such as Istanbul especially after the 1980s, caused the homogeneous scale of the city to be interrupted. This rupture between the vertical rise of physical space and the horizontal plane damaged the sidewalk which is the threshold in public space and caused the dialogue between the built environment and the street to become increasingly reticent. This result could also be caused by the design pattern of predominantly large introverted and profit-oriented shopping centers on the lower floors of these high-rise business centers. Because these shopping centers direct a significant part of the pedestrians to arrive mostly by their cars and lead them directly to the parking areas located on the basement floors, and orient urbanites to spend a significant part of their time in the shopping center. Therefore, the horizontal capillarities that have somehow maintained the vitality of the city for centuries have gradually lost their liveliness, and pedestrians have begun to tend to maintain their encounters in artificial environments, mostly indoors. Besides, the intensive use of CBD areas during daytime, which are mostly working hours, have led these areas become mainly busy during the day, but uncanny areas during night times. When the topic is discussed in terms of the dialogue and interaction between the body and the object, it can be said that the physical effects in the city caused by globalization tend to reduce the bodily experiences due to the loss of vitality in the public domain.

The damage to the vitality of the city harms the younger generations who are the ones that have just started to perceive their nearby built environments, comprehend spatial characteristics and build their orientations in the city through their direct experiences, and would create their own unique urban image depending on their bodily experiences. Indeed, it is inevitable that children who 
are confined to their own ghettos, lacking the experience that the city offers, will have problems not only with the urban environment, but also with social interaction that the urban environment is supposed to present. However, according to David and Weinstein (1987), all the built environment that are designed for children should strengthen personal identity according to the development of the child; should encourage the acquisition of a number of skills; should offer opportunities for growth and also support a sense of security. Moreover, built environments should not only provide certain common functions in the sense of social communication, but also allow the protection of privacy.

\section{International Models to Re-Engage the City with the Body: Homezone and Woonerf Implementations}

Despite the ongoing challenging globalization movements, there are many practices in the world that aim to make the urban environment much more livable for young generations and to give them the opportunity to experience especially for play and recreational activities. The most important initiative to increase the physical experience of the child in the city was the adoption of the concept of a child-friendly city by the end of the twentieth century.

As a part of the Habitat II Conference, which took place in 1996, the concept of a child-friendly city was defined, which aims to make cities livable for all (Tandoğan, 2014). According to the Child Friendly Cities Initiative ( $\mathrm{CFCl}$ ), it was targeted to respond the challenges of increasingly "urbanized and decentralized" world (UNICEF, 2018, p.5). A child-friendly city is defined as an urban domain that has characteristics that can support the child's physical and social development so that the child can become an adult who owns his or her own city in the future.

Within this context, the city needs to be a place where children not only can enjoy and feel safe in a physical sense, but also it can convey to children the message that they are an equal part of society with other people in a symbolic sense, through its design, planning and also the behavior of adults (Churchman, 2003). For this reason, in order for the child to be able to ride a bicycle or a scooter in an urban space, safely reach school and various recreational areas on foot and learn to share through play, the urban space should be able to provide an appropriate physical environment for children with all its spatial components. Besides, it is also necessary and indispensable for them to spend time together with their peers for their social development.

Therefore, it can be said that a child-friendly city should allow children to walk on the streets on their own, to freely meet with their friends, to interact with plants and animals, to live in a clean and sustainable environment, to freely participate into social life and even explain and make decisions about the city they live in (Riggio, 2002). After the concept of child-friendly city was announced at the Habitat II conference, local governments in many countries, from United States of America, to Spain and Sweden, from Croatia, to Bangladesh and India, have started implementing new action programs to ensure that the concept of the child-friendly city was adopted by communities (Riggio, 2002).

Some of these programs and practices were directly related to taking new decisions in urban planning and physical environment of the cities in street scale. Several remarkable decisions have been taken and implemented, especially in Northern European cities and England. These streetscale practices have prioritized the condition for streets to be livable for children again, primarily by making the street accessible to everyone. In other words, in livable street implementations, it is noticed that the safety of the street is not ensured by closing the street physically to prevent the flow of traffic, but rather the traffic is calmed down through design implementations so that the streets eventually admit all types of social actors of the city - children, teenagers, adults, elderly, disabled and etc. Within this context, two different types of implementations applied in Northern Europe and England to create livable streets - Homezone and Woonerf-are mentioned in the scope of this paper since it is thought that these kinds of implementations may also carry a positive 
potential to be applied in metropolitan cities in Turkey where housing pattern is dense and families with children mostly live.

In the 1970s, the Woonerf implementation, which supported to integrate the vehicle traffic with pedestrians in a residential area in Delft, Netherlands, rather than isolating the traffic from pedestrians to keep it safer, was eventually given legal status by the local authorities and the national government due to the positive impact it had. Since the academic studies also showed that this implementation reduced the frequency of traffic accidents, but rather increased the satisfaction of the residents and also the frequencies of socialization and play on the streets, this model has been introduced not only in European countries but has been acclaimed and implemented in many countries on other continents in the world (Ben-Joseph, 1995, p.504). BenJoseph (1995) states that the issue of integrating traffic with the street was first raised by Colin Buchanan through a report published in the UK in 1963. Buchanan, a road engineer and architect, along with his team, supported that some streets in the city should be configured in such a way that traffic is separated from pedestrians, while other streets should be configured in such a way that pedestrians and vehicles safely mix. In time, German and Dutch researchers showed much greater interest in this new urban system, which was not accepted by the UK. Niek de Boer, professor of Urban Planning at Delft University of Technology and University of Emmen, developed a new culde-sac design based on Buchanan's theory to allow more children to play on the streets (BenJoseph, 1995, p.506).

According to van Gameren and Mooij (2018) this concept, which Niek De Boer called Woonerf in Dutch, literally meant "a house located in a yard". Therefore, this word, which evokes the social life in the old village times, furthermore tried to convey the message to urbanites that they can also socialize on the streets of the city with this nostalgic connotation. Although it seems to be a Dutch practice, Woonerf, which soon attracted interest, became a development that received worldwide attention and was practiced globally. Evaluating the woonerf as a revival of the plan configuration of the traditional Dutch village houses, Van Gameren and Mooij $(2018$, p.21) discuss the plan transformation through these words: "With the arrival of the woonerf and the introduction of a collective intermediate space, shifts in the traditional ground plan became an important design theme. The relationship between public and private was redefined, bringing forward some striking contradictions. The space on the house's access side was designed as a communal lot, as an extension of the living area. The sheds and kitchen face the erf, reinforcing the informal character of the outside space, but also forcing the living room to the back of the house. This creates a house in which the living room turns its back on the erf and is oriented towards a protected, private outdoor space."

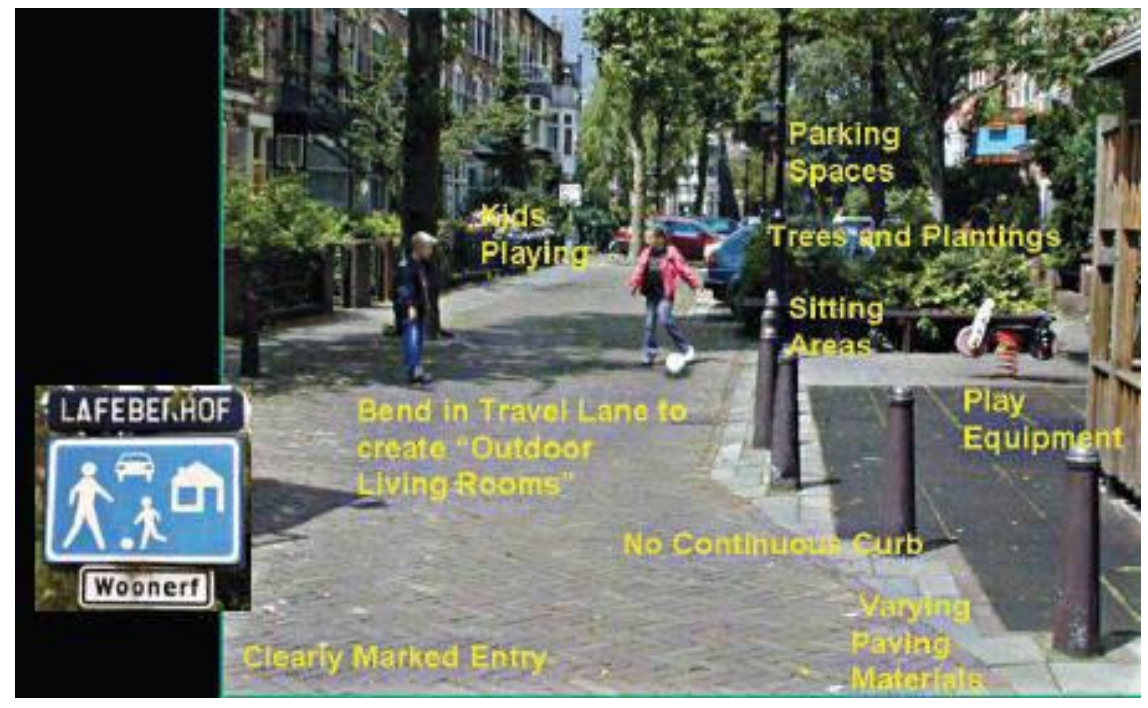

Figure 2 Principles of woonerf design by Appleyard and Cox (2006, p.31; Collarte, 2012). 
The woonerf implementation, of which construction and use standards were set by the Dutch government in 1976 (Guttenberg, 1982), was first implemented in the city of Delft (Tandoğan, 2014). In the woonerf implementation, the street is shared by pedestrians, cyclists and commuters, but pedestrians are superior to the vehicles. This superiority is achieved by the fact that the curb is not continuous and the speed of the vehicles is reduced. Besides, socialization on the street can be more visible and residents' satisfaction is attempted to be ensured by the placement of landscape elements such as planters, trees and urban furniture (Figure 2). By reducing the speed of the car, the street is targeted to be more livable and satisfactory for the pedestrians, and especially for those who live on that street (Collarte, 2014; Dudek, 2019).

Woonerf system, where separating the parking spaces from the residential areas is also an important thought, the front areas of the residential areas can be a good meeting point and large play zones can be opened for children. The street, where hardscape is integrated with the landscape, greenery zones including trees and plants at the front of each residence are arranged in different widths and evaluated as unique in order to both reduce the speed of the vehicles and to eliminate the monotonous layout of the silhouette of the street (Kraaij and Mooij, 2010).

Another urban planning proposal for street design, where pedestrians and vehicles come together within the framework of certain design principles without being separated from each other, is home zone concept. The home zone concept, inspired by the woonerf concept and implemented firstly in the UK, is described on the website of the UK Department for Transport (2005) as follows: "Home Zones are residential streets in which the road space is shared between drivers of motor vehicles and other road users, with the wider needs of residents (including people who walk and cycle, and children) in mind. The aim is to change the way that streets are used and to improve quality of life, by making them places for people, not just for traffic." So, the term home zone, an English terminology instead of woonerf which is a Dutch word, is actually used to refer to the essentially same urban idea regarding the design of the street (Gill, 2006).

Howarth and Preston, who first used the term home zone in the 1990s in their project for a residential area proposal, state that the project prioritizes the child so that any driver who cause an accident should be considered careless (Preston, 1995; Gill, 2006). In 1999, the UK government decided to introduce the first pilot home zone applications in England, in the Wales region and Scotland, and then post-occupancy assessments were made regarding accident reports and residential satisfaction. In home zone applications, there are no strict rules depending on the design of the street, as compared to woonerf. Instead, the Department for Transport has created design guidelines for home area design and planning as Gill (2006) describes through the table below (Table 1). According to these guidelines, the involvement of pedestrians with vehicles is the main rule. Since it is necessary to reduce the speed of the vehicle in order to achieve this sharing, home zone applications also use visual materials and landscape elements that reduces the driver's field of view.

Table 1 The home zone vs. the woonerf (Gill, 2006).

\begin{tabular}{|l|l|l|}
\hline & Home zone & Woonerf or equivalent \\
\hline Legal status & $\begin{array}{l}\text { Not explicitly defined in law: } \\
\text { legislation enables local authorities } \\
\text { to create home zones }\end{array}$ & Explicitly defined in law \\
\hline Design requirements & No statutory guidance & Statutory guidance \\
\hline Shared surface use & Not universal & Required by law \\
\hline $\begin{array}{l}\text { Legal change giving priority for } \\
\text { pedestrians }\end{array}$ & No & Varies from country to country \\
\hline
\end{tabular}



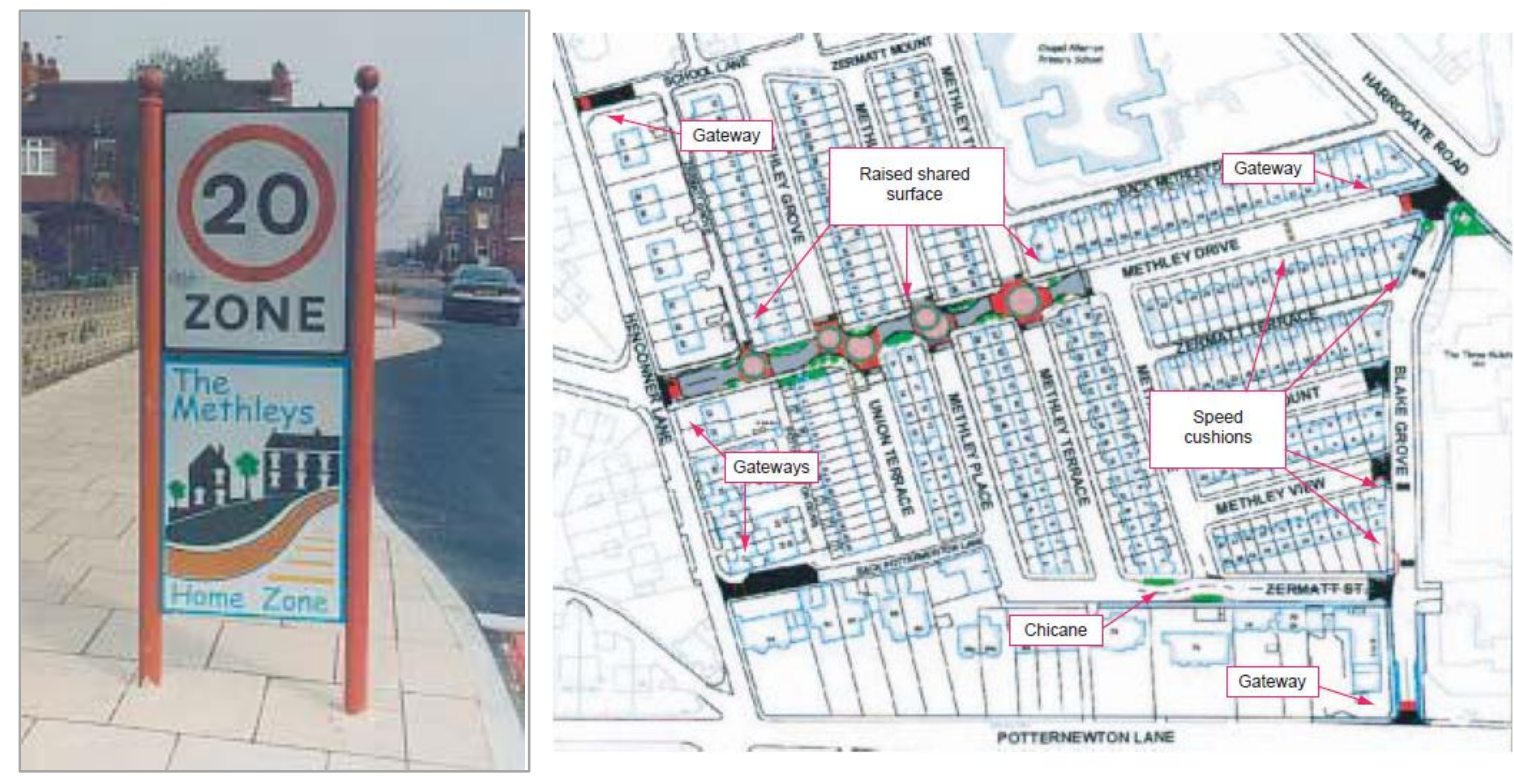

Page $\mid 78$

Figure 3 and Figure 4 Home zone sign (left), an example of a home zone implementation showing Methley Drive (right) (Layfield et al., 2003, p.10).

Layfield et al. (2003), who worked on one of the pilot works in The Methleys region in Leeds describe the design considerations as follows: the entry points of the street are narrowed by physical barriers, with a home zone sign and another sign indicating that it should be driven at 20 $\mathrm{mph}$ (Figure 3 and Figure 4). A different color and also planting is applied in order to show how the shared domain of the street is distributed to both the drivers and pedestrians. Also, some design implementations were applied on some of the important streets in the region to slow down traffic. According to the researchers' study, people living on Methley Drive stated that they were satisfied with the practice in general, that they did not experience the danger of traffic as much as they used to, but that the time they spent on their streets did not increase significantly. Researchers (Layfield et al., 2003) consider the reason for this as the insignificant change in the frequencies of vehicles on the street compared to before and they emphasize that in order to increase the frequency and duration of socialization on the street, the results of interviews with children must be taken into account because the children have expressed their opinion that they especially want a play zone.

The results of interviews with residents about another home zone implementation in the Northmoor, Manchester area show that residents are satisfied that the appearance of the area has improved, that the time spent walking in the area has increased slightly and that there has been no significant change in the amount of accidents; the accident frequency, compared to the situation before the implementation, has reduced from 1.0 to 0.5 per year (Tilly et al., 2005, p.42). However, it is noted that the reduction of vehicle space on the street is considered a problem (Tilly et al., 2005).

According to another study that Biddulph compared the social interaction on two streets (2012), one of which is calmed street and the other is home zone street, it was found that on the street where home zone was applied, pedestrians spend longer time for arbitrary activities and even socialize with others. The results revealed in his study showed that home zone treatments have a positive impact on human interaction in urban life, especially for the families with children. Besides, it has been found that slowing down traffic on a street does not increase children's behavior to spend time outside as it is compared to home zone implementations, but the inclusion of spatial design features covered in home zone street makes the significant positive contribution. 


\section{Child-Friendly Urban Initiatives in Turkey}

Turkey, after having adopted the Convention on the Rights of the Child in 1995, and hosted the Habitat II Conference in 1996, it was decided to launch child-friendly urban initiatives in twelve cities of Turkey. These pilot implementations were initiated in Sivas, Uşak, Gaziantep, Kırşehir, Karaman, Antalya, Kayseri, Erzincan, Konya, Tekirdağ, Bursa and Trabzon (Berkün, 2019, p.144). These projects which were all embraced in a different context than each other are listed as follows:

1. Tekirdağ: Children's Festival

2. Bursa: Science and Technology Center

3. Uşak: Child-Friendly Media Education

4. Antalya: Application to host the World Summit on Media for Children

5. Karaman: Child-Friendly School Project

6. Konya: Baby-Friendly Provincial Practices

7. Kırşehir: Provincial Children's Assembly

8. Kayseri: website service

9. Gaziantep: Child-Friendly Media Logo

10. Sivas: Nutrition-Friendly Schools Project

11. Erzincan: Street League

12. Trabzon: Baby-Friendly Hospital

When the scopes of these projects stated above are examined, it can be immediately noticed that they are not focused on extensive strategies covering the entire city in urban scale; some projects can be considered to be physical implementations in terms of a new building while some other ones such as establishing a web site or design of a logo can be considered to be serviceoriented strategies in terms of communication programs to initiate the concept of a child-friendly city.

When the literature is reviewed, very little academic research was found on the abovementioned projects. Regarding the child-friendly projects held in Tekirdağ, local news mention about the first Children's Festival launched in 2007 that children who were given a voice publicly in the festival raised their demands about new sports spaces from the local authority (Url-1). In the scope of the child-friendly project in Antalya on the other hand, Antalya Congress Bureau and Faculty of Communication of Akdeniz University applied to host the World Summit on Media for Children event at the 2017 Congress (Url-2). Within the context of the child-friendly project in Karaman, various health screenings were performed in schools (Url-3) while implementations were carried out within the framework of making baby-friendly hospitals in Konya (Url-4) and Trabzon. Additionally, regarding the child-friendly Kırşehir project, it was announced on the media that the construction of new parks would be started for children in high-population villages (Url-5), while it was noticed that a new web portal -www.cocukdostukayseri.org- was created where developments about the child-friendly Kayseri could be followed (Url-6). However, it has been observed that it is not possible to access the website in the present time. With the project prepared by the Gaziantep Metropolitan Municipality, it was aimed to create a Children's Council that would supervise the media coverage of children so that the children would be able to supervise the news published about them in the media (Url-7). As a result of the Nutrition-Friendly School Program conducted in Sivas, the city managed to take place within the first 20 cities reaching the number of 209 nutritionfriendly schools in the city (Url-8). Moreover, a football team from Erzurum was included in the street league that is organized specifically for the participation of children at risk (Url-9).

In addition to these service-oriented projects for children stated above, two new implementations in terms of children's spaces attract specific attention. The Science and Technology Center that was founded in Bursa in 2012 aimed to make positive contribution to the informal education of children allowing them to participate in recreational activities (Url-10). Another study within the scope of the child-friendly city projects (Topsümer et.al., 2009), which was 
carried out in Uşak, was based on an interview with the governor of Uşak. The scope of the project carried out in Uşak focused on creating pocket parks near to the city center and also establishing a child-friendly media network.

In addition to these singular implementations mentioned above, the first Children's Municipality project which a whole city heads towards to gain the right of being a child-friendly city, came from Seferihisar, Izmir with the participation of the local government in the International Child in the City conference in 2018, in Wien. Within the scope of the project, it is stated that an old wedding hall was restored and the building with a multi-purpose hall, music room, photography and ceramic workshop, project and activity room was allocated to the Children's Municipality. The Children's Municipality has been directly involved in the work of the Municipality as a decision-making mechanism since 2011, and many projects for young people and children, ceramics, piano, violin, guitar, children's choir, folk dances, chess, painting and theater courses have been being carried on actively (Url-11).

Considering child-friendly initiatives launched since 1996 in Turkey, it is noticed that decisions have not yet been taken to revitalize the streets for children to play, to increase socialization on the streets, to slow down urban traffic, and for children to reach their schools safely on their bicycles or on foot. In this sense, the adoption of new urban strategies in order to make the children meet with the lively urban domain again and conducting concurrent evidence-based research can provide novel knowledge on how important urban-scale decisions are for children's physical, social and cognitive development.

\section{Discussion and Conclusion}

The problems caused by fast but irregular urbanization as a result of social, cultural and physical changes are the most important issues to be solved for the metropolitan cities. Not only industrial movements and migration but also globalization movements at the end of $20^{\text {th }}$ century also affected especially large cities all around the world. This resulting speed and transformative acceleration, which affected the physical appearance of the city intensely, revealed a result that reinforced the affinity and similarity regardless of the typologies of the buildings in the city, where the diversity of mixed buildings on the scale of the neighborhood was lost and the buildings has started to become like each other.

According to Moussavi (2010), in the notion of architectural design, diversity does not only depend on spatial extensity, but also it depends and can be measured with the intensity of the form and the way it affects the body. One of the urban dynamics that most effected the experience of the body in the $21^{\text {st }}$ century was the sharp separation of work spaces and housing fabric in cities due to sociocultural and economic changes. This segregation in cities and the alienation in the neighborhood scale also led to the disappearance of street vitality and "eyes upon the street", which Jacobs (1992) mention that mix-used streets support and have a structure that attract various social groups of the community. Streets, that are the public domains that pedestrians of all ages encounter by chance in the daily life, have begun to lose their liveliness, especially in areas where the city's commercial areas are concentrated. One of the main reasons for this was the construction of highways, especially in metropolitan cities, and the streets were increasingly filled with large amount of cars. The increase in road width and, accordingly, the frequency of vehicles on the roads have also led to an increase in speed limits on the roads.

The main social group affected by this physical change in cities was the young generation, hence the children. In other words, the first social group that this strong change erased the visibility on the streets was unfortunately the children who used to play freely before. Over time, children who were deprived of the freedom to play on streets, that was an important part of their social, emotional, physical and cognitive development, were almost doomed to go to the children's parks only accompanied by their parents. 
In some international cities where this inevitable fact was also experienced, some urban planning strategies have been implemented through academic studies. Woonerf, developed in the UK but implemented firstly in the Netherlands in the 1960s, and home zone, inspired by woonerf in the 1980s and implemented in the UK, were implementations aimed to bring back the social vitality of the streets. Both of these applications were based on reducing the speed of vehicles on the street, narrowing the street entrance with noticeable physical elements to reduce the speed of vehicles, disrupting the linear flow on the street, equipping certain parts of the street with landscape and urban furniture, so that pedestrians can safely spend longer on the street.

In evidence-based research, studies with those living on the streets where woonerf and home zone were applied, it is found out that both the residents socialized more on these streets, and the frequency of children going out and playing on the street increased over time. By means of the theoretical and practical infrastructures of these international experiences, pilot implementation studies can also be carried out in certain regions in our country. With a number of new strategies that local governments and decision-makers in the field of urban design might implement, and with new decisions that can be added to the regulations, pilot calm street implementations can be applied on certain streets dominated by residential areas. The potentials of such implementations can be examined through analysis that can be conducted through evidence-based academic research about these urban implementations, which can be applied with the support of local governments.

Whether positive results can be achieved, children can play with their friends again, ride bikes, and parents can get together more often on these calmed streets. Moreover, these streets can reembrace not only children, but also all individuals of society such as the young, elderly, disabled and so on. Through evidence-based researches that can be done through these pilot applications, assessments of parameters such as safety, accident risk, and socialization can be made and the success of these applications can be assessed and the question of whether these models can be applied more widely can be analyzed in future studies.

\section{References}

Akarsu, B., 1994. Çağdaş Felsefe, Kant'tan Günümüze Felsefe Akımları, İnkılap, İstanbul.

Akgün, T. D., (2010). Karma işlevli yapıların kentsel ve mimari tasarım arakesitinde kamu yararı gözetilerek irdelenmesi: Zincirlikuyu-Levent Aksı örneği, Yüksek Lisans Tezi, Institute of Science and Technology, İstanbul Technical University, Turkey.

Appleyard, B., Cox, L. (2006). At home in the zone. Planning, 72(9).

Ben-Joseph, E. (1995). Changing the residential street scene: Adapting the shared street (woonerf) concept to the suburban environment. Journal of the American Planning Association, 61(4), 504-515.

Berkün, S. (2019). Çocuk Dostu Kent Yönetimlerinin Çocuklar Tarafından Değerlendirilmesi: Bursa Örneği. Business \& Management Studies: An International Journal, 7(1), 135-152.

Bettleheim, B. (1987) The importance of play, The Atlantic Monthly, 259, pp. 35-42.

Biddulph, M. (2012). Street design and street use: comparing traffic calmed and home zone streets. Journal of urban design, 17(2), 213-232.

Bilgin, M., 2006. Karma İşlevli Yapılı Merkezlerin Kent ve Günlük Yaşam İçersisindeki Yeri: İstanbul'dan Örnekler, Yüksek Lisans Tezi, Gazi Üniversitesi, Fen Bilimleri Enstitüsü, Ankara.

Churchman, A. (2003). Is there a place for children in the city? Journal of Urban Design, 8(2), 99-111.

Collarte, N. (2012). The Woonerf Concept "Rethinking a Residential Street in Somerville". Master of Arts in Urban and Environmental Policy and Planning, Tufts University, Cambridge.

Collarte, N. (2014). The American Woonerf: Creating Livable and Attractive Shared Streets, Doctoral dissertation, Tufts University, MA, USA.

David, T.G., Weinstein, C.S. (1987). Built Environments and Children's Development, In C.S. Weinstein, T.G. David, (Eds.), Spaces for Children, (pp. 3-18.) New York: Plenum Press.

UK Department for Transport (2005). "Home Zones." London: Department for Transport.

Dicle, A. (1983). Gecekondu: The problems of internal migration and squatter settlements in Turkey. Journal of South Asian and Middle Eastern Studies 6(3) pp.48-61. 
Dudek, J. (2019). Design Guidelines for Creating a Vital Woonerf Street. International Multidisciplinary Scientific Geo Conference: SGEM, 19(6.2), 433-440.

Geniş, Ş. (2007). Producing elite localities: the rise of gated communities in Istanbul. Urban studies, 44(4), 771-798.

Gill, T. (2006). Home zones in the UK: history, policy and impact on children and youth. Children Youth and Environments, 16(1), 90-103.

Guttenberg, A. Z. (1982). How to crowd and still be kind-The Dutch Woonerf. Humboldt Journal of Social Relations, 100-119.

Jacobs, J. (2011). The uses of sidewalks: safety. In R.T. Le Gates, F. Stout, (Eds.), The City Reader, 105-109, Routledge, New York.

Jacobs, J., 1992. The Death and Life of Great American Cities, Vintage Books, A Division of Random House, Inc., New York.

Keyder, Ç., (2009). Arka Plan, In Ç. Keyder (Ed.), Istanbul Küresel ile Yerel Arasında, 9-40, Metis, Istanbul.

Kraaij, A., Mooij, H. (2010). Plan Documentation: of the Woonerf. DASH/ Delft Architectural Studies on Housing, (03), 73-75.

Kubat, A. S. (2019). Exploring the Fringe-Belt Phenomenon in a Multi-Nuclear City: The Case of Istanbul.ICONARP International Journal of Architecture and Planning, [S.I.], v. 7, p. 95-134, ISSN 21479380. Available at: <http://iconarp.ktun.edu.tr/iconarp/article/view/386>. Date accessed: 20 dec. 2020. doi:http://dx.doi.org/10.15320/ICONARP.2019.83.

Kurtulus, H. (2011). Gated communties as a representation of new upper and middle classes in Istanbul, Journal of Faculty of Political Science, 44, 49-65.

Layfield, R., Chinn, L., \& Nicholls, D. (2003). Pilot home zone schemes: evaluation of The Methleys, Leeds. Wokingham, UK: Transport Research Laboratory.

Moussavi, F., (2010). Biçimin İşlevi (Trans. P.Derviş), YEM, İstanbul.

Noe, A., (2004). Action in Perception, MIT Press, USA.

Merlau-Ponty, M. (2010). Algılanan Dünya, (Trans. Ö. Aygün), Metis, İstanbul.

Preston, B. (1995). Cost Effective Ways to Make Walking Safer for Children and Adolescents, Injury Prevention, 1: $187-190$

Riggio, E. (2002). Child friendly cities: good governance in the best interests of the child. Environment and Urbanization, 14(2), 45-58.

Spencer, C. \& Woolley, H. (2000) Children and the city: a summary of recent environmental psychology research, Child: Care, Health and Development, 26(3), pp. 181-198.

Tandoğan, O. (2014). Çocuk İçin Daha Yaşanılır Bir Kentsel Mekan: Dünyada Gerçekleştirilen Uygulamalar. Megaron, 9 (1).

Tas, H.I. and Lightfoot, D.R. (2005). Gecekondu Settlements in Turkey: Rural-Urban Migration in the Developing European Periphery, Journal of Geography, 104(6), pp.263-271.

Tilly, A., Webster, D., \& Buttress, S. (2005). Pilot home zone schemes: evaluation of Northmoor, Manchester. Wokingham, UK: Transport Research Laboratory.

Topsümer, F., Babacan, E., Baytekin, E. P. (2009). Şehir ve çocuk: Çocuk dostu şehir girişiminin şehir imajına katkısı. Istanbul Üniversitesi Iletişim Fakültesi Dergisi| Istanbul University Faculty of Communication Journal, (35), 5-20.

UNCRC (1989). Convention on the Rights of the Child, Retrieved from: https://www.ohchr.org/en/professionalinterest/pages/crc.aspx in Dec. $20^{\text {rd }}, 2020$.

United Nations Children's Fund (UNICEF), April 2018. Child Friendly Cities and Communities Handbook. Retrieved from: https://www.unicef.org/eap/reports/child-friendly-cities-and-communities-handbook, in Nov. 29th 2020.

Url-1 Tekirdağ'da 1. Çocuk Festivali Başladı, Retrieved from: https://www.haberler.com/tekirdag-da-1-cocukfestivali-basladi-haberi/ in Dec. 20 2020.

Url-2 Çocuk Dostu Kent Antalya, Retrieved from:https://www.sabah.com.tr/akdeniz/2013/10/19/cocukdostu-kent-antalya in Dec. 20 2020.

Url-3 Karaman il Sağlık Müdürlüğü "Çocuk Dostu Okul Projesi" Kapsamında Öğrencileri Ağız Taramasından Geçirdi. Retrieved from: https://www.haberler.com/karaman-da-cocuk-dostu-okul-projesi-haberi/ in Dec. $25^{\text {th }}, 2020$.

Url-4 Sağlık Bakanlığı yetkilileri Konya'da inceleme yaptı. Retrieved from: https://www.konyakent.com/saglikbakanligi-yetkilileri-konya-da-inceleme-yapti/1549/ in Dec. $20^{\text {th }}, 2020$. 
Url-5 Kırşehir'de II Özel Idare Müdürlüğü Kaynaklarıyla, Nüfusu Yüksek Olan Köylere Çocuk Parkları Yapılacağı Bildirildi. Retrieved from: https://www.sondakika.com/haber/haber-koylere-park-projesi-hayatagececek/ in Dec. $20^{\text {th }}, 2020$.

Url-6 Kayseri Valiliği'nce yürütülen Çocuk Dostu Şehir Projesi kapsamında oluşturulan web sitesinin hizmet vermeye başladığı bildirildi. Retrieved from: https://www.haberler.com/kayseri-de-cocuk-dostu-sehirprojesi-web-sitesi-haberi/ in Dec. $20^{\text {th }}, 2020$.

Url-7 Büyükşehir Belediyesi, çocukları medya ile buluşturuyor. Retrieved from: https://www.haberler.com/buyuksehir-belediyesi-cocuklari-medya-ile-2385179-haberi/ in Dec. $20^{\text {th }}$, 2020.

Url-8 Beslenme Dostu Okul Projesi. Retrieved from: https://sivasism.saglik.gov.tr/TR,112347/beslenmedostu-okul-projesi.html in Dec. 20 2020.

Url-9 Sokak ligi İzmir'de buluşuyor. Retrieved from: https://www.izmir.bel.tr/tr/Haberler/sokak-ligi-izmirdebulusuyor/2733/156 in Dec. $20^{\text {th }}, 2020$.

Url-10 Bursa'nın uzay yolculuğu başladı, Retrieved from: http://www.bursabilimmerkezi.org/kategori/haberler-13/ in Dec. 20 2020.

Url-11 Çocuk Belediyesi dünyaya model., Retrieved from: http://seferihisar.bel.tr/cocuk-belediyesi-dunyayamodel/ in Dec. $20^{\text {th }}, 2020$.

van Gameren, D., \& Mooij, H. (2018). The Heritage of the Woonerf. DASH/ Delft Architectural Studies on Housing, (03), 18-29.

von Leyden, W. (1962, January). Cogito, ergo sum. In Proceedings of the Aristotelian Society, Vol. 63, pp. 6782, Aristotelian Society, Wiley.

Wegenstein, B., 2006. Making Room for the Body: From Fragmentation to Mediation, In M. Flanagan, A. Booth (Eds.), Re-skin, MIT Press, USA.

Werner, C. M., Altman, I. (2000). Humans and nature: insights from a transactional view. In S. Wapner, J. Demick, T. Yamamoto, H. Minami (Eds.), Theoretical Perspectives in Environment-Behavior Research Underlying Assumptions, Research Problems and Methodologies, pp.21-37, Springer, Boston, MA.

\section{Resume}

Nevset Gul Canakcioglu, obtained her B.Sc. degree in architecture in 2002, M.Sc. degree in 2011 with the dissertation titled "Analysis of Perceptual Processes of Children Living in Different Settled Social Groups in Istanbul by the Method of Cognitive Maps" and her Ph.D. degree in 2016, from Istanbul Technical University with the dissertation titled "Analysis of Perceptual Processes of Individuals Using Paediatric Healthcare Spaces by the Method of Cognition and Space Syntax". Worked in various architecture offices and construction companies as technic office architect and project coordinator, participated in a number of architectural project competitions both individually and with different teams. She worked at Istanbul Okan University as a research assistant in 2011-2012. She has published nationally and internationally. Her research focuses on paediatric healthcare environments, spatial perception in children, cognition, behaviour maps, cognitive maps and space syntax in her academic studies. She currently teaches in the Faculty of Architecture and Design at Istanbul Ozyegin University. 